\title{
Analisis Strategi Brand Awareness (Top Of Mind, Brand Recall, Brand Recognition, Unaware Of Brand) Sepeda Motor Piaggio Vespa Di Jakarta
}

\author{
Rina Ayu Vildayanti \\ Fakultas Ekonomi dan Bisnis, Universitas Budi Luhur, Jakarta
}

\begin{abstract}
One of the most important thing of transportation is a motorcycle which is able to comply the level of people needs, because using a motorcycle can support various kinds of people activities to become more practical, economical and easy to drive.This research was intend to analyze the strategy of brand awareness Piaggio Vespa motorcycle in Jakarta, through elements Top of Mind, Brand Recall, Brand Recognition dan Unaware of Brand. The result of this study indicate that strategy of Brand Awareness Piaggio Vespa has been Top Of Mind which has made Piaggio Vespa the first scooter motorcycle to be caught by all respondents. Strategy of Brand Awareness Piaggio Vespa with Brand Recall approach, respondents stated that Piaggio Vespa is a type of scooter that is often heard whwn meeting friends or family. Meanwhile strategy of Brand Awareness Piaggio with Brand Recognition approach, respondents stated that Piaggio Vespa is a type of scooter that has good quality, proven technology and affordable price. Piaggio Vespa is not included by Unaware of Brand category.
\end{abstract}

Keywords : Brand Awarness, Top of Mind, Brand Recall, Brand Recognition Unaware of Brand

\section{Pendahuluan}

Transportasi sangat penting digunakan untuk mengangkut manusia, hewan, dan barang ketempat tujuan. Transportasi yaitu memindahkan manusia, hewan ataupun barang dari tempat asal ketempat tujuannya dengan memakai suatu alat yang dapat digerakkan oleh makhluk hidup ataupun mesin (Miro, Fidel, 2012). Fungsi transportasi adalah melancarkan terjadinya pergerakan manusia (movement of people), melancarkan pergerakan barang (movement of goods) dan melancarkan pergerakan jasa/informasi (movement of service/information) dengan prasarana yang telah disiapkan. Transportasi menjadi persoalan yang memerlukan perhatian dari berbagai perspektif ilmu (Schipper, 2002). Untuk wilayah perkotaan, transportasi memegang peranan cukup menentukan dengan melihat salah satu wujud indikasi kota yang baik tercermin dari kondisi transportasinya. Transportasi 
yang baik, aman dan lancar selain mencerminkan keteraturan kota, juga memperlihatkan kelancaran kegiatan perekonomian kota tersebut.

Salah satu alat transportasi yang sangat penting adalah sepeda motor yang mampu memenuhi tingkat kebutuhan masyarakat, karena dengan menggunakan sepeda motor dapat mendukung berbagai macam aktifitas masyarakat agar menjadi lebih praktis, ekonomis dan mudah dalam berkendara. Sepeda motor juga tepat untuk segala kondisi jalan, sehingga menjadikan sepeda motor sebagai sarana transportasi yang penting bagi konsumen dibanding dengan alat transportasi lainnya. Hal ini memacu para produsen otomotif kendaraan bermotor untuk menciptakan inovasi baik dari segi mutu, model dan teknologi produk untuk mendapatkan simpati dari konsumen, seperti terlihat dari kondisi persaingan dunia bisnis otomotif sekarang yang telah banyak mengalami perkembangan teknologi dan berkembang pesat di dunia.

Pada saat ini, kehidupan masyarakat modern turut mempengaruhi pola perilaku masyarakat dalam pembelian yang seringkali identik dengan gaya hidup mengikuti trend atau perkembangan zaman. Ada beberapa faktor yang mempengaruhi keputusan pembelian suatu produk, yaitu kesadaran merek (brand awareness) dan kepercayaan konsumen atas merek. Merek (brand) menjadi elemen yang penting bagi perusahan. Merek bukan hanya nama logo atau simbol, tapi memiliki peranan yang jauh lebih besar. Merek dapat berperan sebagai payung representasi produk barang atau jasa yang ditawarkan, dapat berperan sebagai perusahaan, dapat berperan sebagai orang tua atau bahkan dapat berperan sebagai Negara (Kartajaya, 2009). Hermawan Kartajaya, mendefinisikan merek (brand) adalah asset yang menciptakan nilai (value) bagi pelanggan dengan meningkatkan kepuasan dan menghargai kualitas. Merek (brand) juga sebagai asset yang menggambarkan peran, merek (brand) tidak hanya sebagai representasi dari produk yang dimiliki tapi juga harus dapat berfungsi untuk menciptakan nilai bagi pelanggan. Keputusan memillih merek turut berperan dalam gaya hidup modern, sehingga keinginan untuk membeli produk yang bermerek turut mewarnai pola konsumsi seseorang.

Merk yang telah ternama biasanya dijadikan simbol sebagai suatu produk 
yang sukses, sehingga kesadaran merek (brand awareness) turut berpengaruh terhadap kondisi emosional konsumen. Kesadaran merek (brand awareness) adalah kesanggupan seorang calon pembeli untuk mengenali, mengingat kembali suatu merek sebagai bagian dari suatu kategori produk tertentu (Aaker, 1996). Brand awareness memberikan banyak value, antara lain: memberikan tempat bagi asosiasi terhadap merek, memperkenalkan merek, merupakan sinyal bagi keberadaan, komitmen, dan substansi merek, dan membantu memilih sekelompok merek untuk dipertimbangkan dengan serius.

Jika konsumen memiliki persepsi yang baik terhadap merek, maka akan mempengaruhi terbentuknya pilihan produk yang akan dibeli, selanjutnya akan membentuk sikap positif yang nantinya akan mempengaruhi keputusan pembelian. Demikian halnya dengan keputusan pembelian sepeda motor yang dipengaruhi oleh produk, harga dan juga pendapatan disamping faktor gaya hidup. Gaya hidup modern merupakan salah satu faktor individu yang dapat mempengaruhi perilaku pembelian seseorang termasuk terhadap pembelian sepeda motor. Piaggio vespa memiliki banyak varian scooter yang menjadi andalan bagi masyarakat. Bagi pengguna kendaraan bermotor pasti mengenal dan pernah mendengar kata "vespa", vespa adalah scooter tua yang sangat familiar, scooter tua yang masih eksis sampai di era modern ini masih sering terlihat. Bentuk body yang unik dan berbeda dengan kendaraan roda dua lainnya, design yang menarik serta sejarah yang dimilikinya, sehingga inilah yang membuat vespa tetap diminati karena berbeda dengan kendaraan roda dua lainnya, menjadi pusat perhatian di jalan dan bisa bertahan sampai sekarang karena digemari oleh komunitas masyarakat luas.

Brand Awareness merupakan daya ingat konsumen atau calon konsumen tentang produk suatu perusahaan. Ada beberapa faktor yang mempengaruhi Brand Awareness diantaranya logo, gambar, slogan serta mudahnya nama merek sebuah produ, tapi juga harus dapat berfungsi untuk menciptakan nilai bagi pelanggan dan meningkatkan volume penjualan.

Kemampuan konsumen mengingat sebuah produk juga memiliki beberapa tingkatan. Ini menjadi ukuran dimana posisi Brand Awareness produk atau perusahaan. Tingkatan Brand Awareneess adalah tidak mengenal produk (Unaware 
of Brand), mengenal produk (Brand Recognition), mengingat produk (Brand Recall) dan puncak ingatan (Top Of Mind). (Lembing.com : Brand Awareness).

Berdasarkan latar belakang diatas maka kajian ini bertujuan untuk menjabarkan secara deskriptif Analisis Strategi Brand Awareness (Top Of Mind, Brand Recall, Brand Recognition, Unaware of Brand) Sepeda Motor PIAGGIO VESPA di Jakarta tahun 2018.

\section{Tinjauan Teori}

\section{Industri Otomotif}

Industri Otomotif ialah mernacang, mengembangkan, memproduksi, memasarkan, dan menjual serta melakukan purna jual kendaraan bermotor. Otomotif biasanya akan dikaitkan dengan motor atau mesin yang dapat menggerakkan benda yang lebih besar daripada mesin atau motor penggerak. Otomotif juga mempunyai kaitan yang sangat erat dengan dunia industri dan transportasi, dimana kedua bidang tersebut pada umumnya akan menggunakan tenaga mesin atau motor untuk menggerakkan alat pada mobil, motor, bus, dan alatalat besar yang sering kali digunakan di industry-industri besar. Namun sayangnya sebagian besar orang awam yang tidak mengenal lebih jauh tentang pengertian otomotif akan menyamakan istilah otomotif dengan berbagai macam alat transportasi seperti mobil, motor, dan bus, bahkan ada sebagian orang yang menganggap istilah otomotif sama dengan mobil. Tentu saja anggapan ini sangat salah karena pada dasarnya istilah otomotif lebih mengacu pada mesin atau motor sebagai sumber penggerak mobil atau jenis transportasi lainnya bukan sebagai mobilnya.

\section{Merek (Brand)}

Merek (brand) menjadi elemen yang penting bagi perusahan, bukan hanya nama logo atau simbol, tapi memiliki peranan yang jauh lebih besar daripada itu. Merek (brand) dapat berperan sebagai payung representasi produk barang atau jasa yang ditawarkan dapat berperan sebagai perusahaan dapat berperan sebagai orang tua atau bahkan dapat berperan sebagai Negara (Kartajaya, 2007).

American Marketing Association mendefinisikan merek sebagai berikut : "Brand is a name, term, sign, symbol or design, or a combination of them, intended 
to identify the goods or service of one seller or group of sellers and to differentiate them from those of competitors".

Merk (brand) bisa berupa nama, symbol, tanda, desain, atau kombinasi semuanya yang dapat menggambarkan segala sesuatu baik berupa barang maupun jasa yang dapat ditawarkan kepada pelanggan baik berupa barang atau jasa yang harus memiliki nilai yang unik dan berbeda dari pesaing.

Hermawan Kartajaya (2009) mendefinisikan merek (brand) adalah asset yang menciptakan nilai (value) bagi pelanggan dengan meningkatkan kepuasan dan menghargai kualitas. Merek (brand) juga sebagai asset yang menggambarkan peran, merek (brand) tidak hanya sebagai representasi dari produk yang dimiliki, tapi juga harus dapat berfungsi untuk menciptakan nilai bagi pelanggan dan meningkatkan volume penjualan.

\section{Brand Awareness}

Brand awareness is the ability of a potential buyer to recognize or recall that a brand is a member of a certain product category. Brand awareness memberikan banyak nilai (value), antara lain: memberikan tempat bagi asosiasi terhadap merek, memperkenalkan merek, merupakan sinyal bagi keberadaan, komitmen, dan substansi merek, dan membantu memilih sekelompok merek untuk dipertimbangkan dengan serius (Kartajaya, Hermawan. 2007).

\section{Brand Awareness : Top of Mind}

Top of Mind, pada tahapan ini pelanggan mengingat merek sebagai yang pertama kali muncul di pikiran saat berbicara mengenai kategori produk dari merek tersebut, contohnya : Lifebouy menjadi merek favorit karena fungsi ganda sebagai sabun mandi dan juga sabun kesehatan (Kartajaya, 2007).

\section{Brand Awareness : Brand Recall}

Brand Recall, pada tahapan ini pelanggan mampu mengingat merek tanpa diberikan stimulus, contohnya : Lux disebut pasar setelah adanya stimulus mengenai merek tersebut (Kartajaya, 2007).

\section{Brand Awareness : Brand Recognition}

Brand recognition, pada tahapan ini pelanggan mampu mengidentifikasi merek yang disebutkan, contohnya : Dove disebutkan pasar dengan 
mengidentifikasi mereknya (Kartajaya, 2007).

\section{Brand Awareness : Unaware of Brand}

Pada tahap unaware of brand pelanggan merasa ragu atau tidak yakin apakah sudah mengenal merek yang disebutkan atau belum. Tingkatan ini yang harus dihindari oleh perusahaan. Sebagai contoh, Asepso menjadi merek sabun mandi yang tidak begitu dikenal pasar, karena positioning sabun tersebut sebagai sabun antiseptic (Kartajaya, 2007)

\section{Metodologi Penelitian}

Penelitian ini menggunakan metode deskriptif kuantitatif karena data yang diperoleh dari sampel populasi penelitian dianalisis sesuai dengan metode statistik yang digunakan kemudian diinterpretasikan. Menurut Nazir (2009) metode deskriptif adalah studi untuk menemukan fakta dengan interprestasi yang tepat. Jenis data yang dikumpulkan pada penelitian ini terdiri dari data kuantitatif yaitu data yang dinyatakan dalam bentuk angka dan data kualitatif yaitu data yang berbentuk kalimat atau uraian.

Penelitian ini menggunakan teknik pengumpulan data dalam bentuk data primer melalui penyebaran kuisioner yaitu teknik pengumpulan data yang dilakukan dengan cara memberi seperangkat pertanyaan atau pernyataan tertulis kepada responden untuk dijawab (Sugiyono, 2005). Sumber data diperoleh dengan proses penyebaran kuesioner langsung kepada pengguna kendaraan bermotor roda dua merek Piaggio Vespa yang berada di wilayah Jakarta. Hasil kuesioner akan menjadi sumber perolehan data mengenai topik yang akan dibahas.

Dalam menganalisis data penelitian yaitu bersifat kuantitatif, deskriptif dan interpretatif. Penyajian hasil analisis data penelitian ini dilakukan secara deskriptif kuantitatif bertujuan untuk menemukan fakta-fakta akurat baru dan akan mengkaji lebih dalam tentang tentang Brand Awareness (Top of Mind, Brand Recall, Brand Recognition, Unaware of Brand) Sepeda Motor Piaggio Vespa dengan menggunakan teknik deskriftif interpretatif artinya hasil analisis dipaparkan dan diinterpretasikan sesuai dengan teori dan kerangka pemikiran yang berlaku umum.

\section{Hasil Dan Pembahasan}




\section{Gambaran Umum Piaggio Vespa}

Piaggio merupakan sebuah perusahaan yang didirikan pada tahun 1884 di Genoa, Italia, oleh Rinaldo Piaggio. Pada saat itu perusahaan ini memproduksi mulai dari perlatan kapal, rel kereta, gerbong kereta, body truk, mesin, kereta api, bahkan setelah Perang Dunia I perusahaan ini membuat pesawat dan kapal laut. Pada akhir Perang Dunia II usai, di sinilah Enrico Piaggio anak dari Rinaldo Piaggio mengambil alih Piaggio dari ayahnya. Pada saat itu perekonomian di Italia sedang buruk, lalu Enrico memutuskan untuk mendesain alat trasportasi murah dan bekerjasama dengan D'Ascanio yaitu insinyur di bidang penerbangan yang membuat revolusi kendaraan baru, dengan membayangkan kendaraan dengan menggunakan "monocoque" yaitu garpu depan yang menjepit ban seperti pesawat sehingga mudah untuk penggantian ban baru, dan hasilnya sebuah desain, yang terinspirasi dari pesawat, yang sampai saat ini berbeda dengan kendaraan lain.

Pada tahun 1943 lahirlah pertama kali produk dengan seri MP5 (moto piaggio 5) Paperino. MP5 ini disebut Paperino karena bentuknya yang mirip dengan donald duck, lalu D'Ascanio memperbaiki model tersebut, mengkonsep dan mendesain ulang kendaraannya. Dan lahirlah prototipe MP6, dengan model yang baru, lalu pada saat Enrico Piaggio melihat prototipe MP6 dan secara tidak sengaja dia menyebut "sambra una vespa" akhirnya kendaraan ini dinamakan Vespa, pada April tahun 1946 dan diproduksi masal di pabrik Piaggio di Pontedera, Italia.

Masuknya Vespa di Indonesia, awalnya karena diberikan penghargaan oleh pemerintah terhadap pasukan penjaga perdamaian Indonesia yang bertugas di Congo saat itu. Setelah banyak pengguna Vespa mengendarai Vespa Congo di jalanan, mulailah "demam Vespa" di Indonesia, bahkan sampai saat ini banyak sekali varian Vespa di Indonesia. Indonesia juga menjadi salah satu negara dengan populasi vespa terbesar di dunia. Dan seiring dengan berkembangnya zaman selain ditunjang oleh kondisi ekonomi yang semakin membaik dan sepeda motor dewasa ini sudah menjadi alat transportasi utama masyarakat dari berbagai kalangan masyarakat kota, namun di sisi lain, persaingan di industri bisnis otomotif terlihat semakin ketat dan kompetitif. Piaggio khususnya jenis scooter pertama didunia yaitu Vespa yang telah cukup lama berpengalaman dalam dunia otomotif, sangat 
memahami bagaiamana menciptakan dan membangun Brand Awareness. Dalam penelitian ini akan melihat dan membuat kajian ilmiah bagaimana PiaggioVespa menciptakan dan membangun Brand Awareness melalui elemen : Top of Mind, Brand Recall, Brand Recognition, dan Unaware of Brand.

\section{Deskriptif Data Profil Vespa di Jakarta}

\section{a. Generasi Vespa yang Dikendarai}

Data kategori Vespa yang dikendarai saat ini, diperoleh dari penyebaran kuisioner sebesar 100 (seratus) responden yang dilakukan selama bulan Agustus sampai dengan bulan November tahun 2018. Berikut Data Kategori Vespa Yang Dikendarai ditampilkan pada Tabel 1.

\begin{tabular}{|c|c|c|}
\hline \multicolumn{2}{|c|}{ Pengguna Vespa Modern } & \multirow{2}{*}{$\begin{array}{c}100 \\
94\end{array}$} \\
\hline A & Ya & \\
\hline B & Tidak & 6 \\
\hline
\end{tabular}

Sumber : Data diolah, 2018

\section{b. Usia}

Data Usia diperoleh dari penyebaran kuisioner sebesar 100 (seratus) responden yang dilakukan selama bulan Agustus sampai dengan bulan November tahun 2018. Berikut Data tentang Usia ditampilkan pada Tabel 2

Tabel 2. Usia

\begin{tabular}{|l|l|c|}
\hline \multicolumn{2}{|c|}{ Usia (Tahun) } & $\mathbf{1 0 0}$ \\
\hline A & $17-25$ & 86 \\
\hline B & $26-35$ & 15 \\
\hline C & $36-45$ & 1 \\
\hline D & $>45$ & 0 \\
\hline
\end{tabular}

Sumber : Data diolah, 2018

\section{c. Jenis Pekerjaan}

Data Jenis Pekerjaan diperoleh dari penyebaran kuisioner sebesar 100 (seratus) responden yang dilakukan selama bulan Agustus sampai dengan bulan November tahun 2018. Berikut Data tentang Jenis Pekerjaan ditampilkan pada Tabel 3.

Tabel 3. Jenis Pekerjaan

\begin{tabular}{|c|c|c|}
\hline \multicolumn{2}{|c|}{ Pekerjaan } & 100 \\
\hline A & Pegawai & 35 \\
\hline
\end{tabular}




\begin{tabular}{|c|l|c|} 
B & Mahasiswa/Pelajar & 52 \\
\hline C & Pengusaha & 6 \\
\hline D & Lain-lain & 7 \\
\hline
\end{tabular}

\section{d. Jenis Kelamin}

Data Jenis Kelamin diperoleh dari penyebaran kuisioner sebesar 100 (seratus) responden yang dilakukan selama bulan Agustus sampai dengan bulan November tahun 2018. Berikut Data Jenis Kelamin ditampilkan pada Tabel 4.

Tabel 4. Jenis Kelamin

\begin{tabular}{|c|l|c|}
\hline \multicolumn{2}{|c|}{ Jenis Kelamin } & 100 \\
\hline A & Pria & 84 \\
\hline B & Wanita & 16 \\
\hline
\end{tabular}

\section{e. Jenis Vespa yang Digunakan}

Data Jenis Motor Vespa yang Digunakan diperoleh dari penyebaran kuisioner sebesar 100 (seratus) responden yang dilakukan selama bulan Agustus sampai dengan bulan November tahun 2018. Berikut Data tentang Jenis Motor Vespa yang Digunakan ditampilkan pada Grafik dan Tabel 5

Tabel 5. Jenis Vespa yang Digunakan

\begin{tabular}{|c|l|c|}
\hline \multicolumn{2}{|c|}{ Jenis Motor Vespa yang Digunakan } & 100 \\
\hline A & Vespa LX125 & 18 \\
\hline B & Vespa LX150 3V & 19 \\
\hline C & Vespa LXV 150 3V & 6 \\
\hline D & Vespa S 3V & 8 \\
\hline E & Vespa Primavera & 17 \\
\hline F & Vespa Sprint & 24 \\
\hline G & Vespa GTS Super & 8 \\
\hline
\end{tabular}

\section{f. Lamanya Kepemilikan Motor Vespa}

Data Lamanya Kepemilikan Motor Vespa diperoleh dari penyebaran kuisioner sebesar 100 (seratus) responden yang dilakukan selama bulan Agustus sampai dengan bulan November tahun 2018. Berikut data tentang Lamanya Kepemilikan Motor Vespa ditampilkan pada Tabel 6. 
Tabel 6. Lamanya Kepemilikan Motor Vespa

\begin{tabular}{|c|c|c|}
\hline \multicolumn{2}{|c|}{ Lamanya Kepemilikan Motor Vespa } & $\mathbf{1 0 0}$ \\
\hline A & $<2$ Tahun & 59 \\
\hline B & 3 - 5 Tahun & 35 \\
\hline C & 6 - 8 Tahun & 1 \\
\hline D & $>$ 8 Tahun & 5 \\
\hline
\end{tabular}

\section{g. Alasan Menggunakan Vespa}

Data Alasan Menggunakan Vespa diperoleh dari penyebaran kuisioner sebesar 100 (seratus) responden yang dilakukan selama bulan Agustus sampai dengan bulan November tahun 2018. Berikut data tentang Alasan Menggunakan Vespa ditampilkan pada Grafik dan Tabel 7.

\section{Tabel 7. Alasan Menggunakan Vespa}

\begin{tabular}{|c|l|c|}
\hline \multicolumn{2}{|c|}{ Alasan Menggunakan Vespa } & 100 \\
\hline A & Teknologi Teruji & 8 \\
\hline B & Praktis dan Mudah Perawatan & 6 \\
\hline C & Fashion (Model) & 52 \\
\hline D & Gaya Hidup & 34 \\
\hline
\end{tabular}

\section{h. Penghasilan Per Bulan}

Data Penghasilan Per Bulan diperoleh dari penyebaran kuisioner sebesar 100 (seratus) responden yang dilakukan selama bulan Agustus sampai dengan bulan November tahun 2018. Berikut data tentang Penghasilan Per Bulan ditampilkan pada Grafik dan Tabel 8.

\section{Tabel 8. Penghasilan Per Bulan}

\begin{tabular}{|c|l|c|}
\hline \multicolumn{2}{|||}{ Penghasilan Per Bulan } & $\mathbf{1 0 0}$ \\
\hline A & $<10$ Juta & 86 \\
\hline B & 10 - 20 Juta & 9 \\
\hline C & 21 - 30 Juta & 5 \\
\hline D & $>$ 30 Juta & 0 \\
\hline \multicolumn{2}{|c|}{ Sumber : Data diolah, 2018 }
\end{tabular}

\section{Hasil Analisa Data}

\section{1) Analisa Brand Awareness (Top of Mind)}

Top of Mind, pada tahapan ini pelanggan mengingat merek sebagai yang pertama 
kali muncul di pikiran saat berbicara mengenai kategori produk dari merek tersebut.

a. Sepeda motor Piaggio Vespa merupakan pilihan pertama dalam membeli sepeda motor jenis scooter

Tabel 9. Sepeda motor Piaggio Vespa merupakan pilihan pertama dalam membeli sepeda motor jenis scooter

\begin{tabular}{|c|l|c|}
\hline \multicolumn{2}{|c|}{ Sepeda motor Piaggio Vespa pilihan pertama } & 100 \\
\hline A & Ya & 88 \\
\hline B & Tidak & 12 \\
\hline
\end{tabular}

Dari hasil kuisioner yang diajukan kepada 100 (seratus) responden Pengendara Piaggio Vespa tentang pilihan motor jenis scooter, maka diperoleh hasil 88 (88\%) menyatakan Piaggio Vespa merupakan pilihan pertama, sementara 12 (12\%) menyatakan Piaggio Vespa bukan merupakan pilihan pertama.

b. Logo Piaggio Vespa mudah diidentifikasi sebagai sepeda motor jenis scooter Tabel 10. Logo Piaggio Vespa Mudah Diidentifikasi sebagai Sepeda Motor Jenis Scooter

\begin{tabular}{|c|c|c|}
\hline & Logo Piaggio Vespa mudah diidentifiikasi & \multirow{2}{*}{100} \\
\hline \multicolumn{2}{|r|}{ sebagai sepeda motor jenis scooter } & \\
\hline A & $\mathrm{Ya}$ & 98 \\
\hline B & Tidak & 2 \\
\hline
\end{tabular}

Sumber : Data diolah, 2018

Dari hasil kuisioner yang diajukan kepada 100 (seratus) responden Pengendara Piaggio Vespa tentang Logo Piaggio Vespa mudah diidentifikasi sebagai sepeda motor jenis scooter, maka diperoleh hasil 98 (98\%) menyatakan Logo Piaggio Vespa mudah diidentifikasi sebagai sepeda motor jenis scooter, sementara $2(2 \%)$ menyatakan Logo Piaggio Vespa tidak mudah diidentifikasi.

c. Logo Piaggio Vespa mudah diingat oleh orang

Tabel 11. Logo Piaggio Vespa Mudah Diingat oleh Orang

\begin{tabular}{|l|l|c|}
\hline \multicolumn{2}{|c|}{ Logo Piaggio Vespa mudah diingat oleh orang } & $\mathbf{1 0 0}$ \\
\hline A & Ya & 99 \\
\hline B & Tidak & 1 \\
\hline
\end{tabular}


Dari hasil kuisioner yang diajukan kepada 100 (seratus) responden Pengendara Piaggio Vespa tentang Logo Piaggio Vespa mudah diingat oleh orang, maka diperoleh hasil 99 (99\%) menyatakan Logo Piaggio Vespa mudah diingat orang, sementara $1(1 \%)$ menyatakan Logo Piaggio Vespa tidak mudah diingat.

\section{2) Analisa Brand Awareness (Brand Recall)}

Brand Recall, pada tahapan ini pelanggan mampu mengingat merek tanpa diberikan stimulus.

a. Piaggio Vespa merupakan motor jenis scooter yang sering disebut oleh masyarakat

Tabel 12. Piaggio Vespa Merupakan Motor Jenis Scooter yang Sering Disebut oleh Masyarakat

\begin{tabular}{|c|l|c|}
\hline \multicolumn{2}{|c|}{$\begin{array}{c}\text { Piaggio Vespa sering disebut sebagai sepeda } \\
\text { motor jenis scooter }\end{array}$} & 100 \\
\hline A & Sering & 79 \\
\hline B & Jarang & 20 \\
\hline C & Tidak Pernah & 1 \\
\hline
\end{tabular}

Dari hasil kuisioner yang diajukan kepada 100 (seratus) responden pengendara Piaggio Vespa tentang seberapa sering responden menyebut nama Piaggio Vespa sebagai sepeda motor Jenis Scooter, dimana hasil penelitian memperlihatkan 79 (79\%) menyatakan sering menyebut Piaggio Vespa sebagai sepeda motor jenis scooter, sementara 20 (20\%) menyatakan jarang menyebut Piaggio Vespa sebagai sepeda motor jenis scooter, sedangkan 1 (1\%) menyatakan tidak pernah menyebut Piaggio Vespa sebagai sepeda motor jenis scooter.

b. Piaggio Vespa merupakan motor jenis scooter yang sering didengar ketika bertemu dengan teman/keluarga

Tabel 13. Piaggio Vespa merupakan motor jenis scooter yang sering didengar ketika bertemu dengan teman/keluarga

\begin{tabular}{|l|l|c|}
\hline \multicolumn{2}{|l|}{ Piaggio Vespa sering didengar ketika bertemu dengan teman/keluarga } & 100 \\
\hline A & Sering & 63 \\
\hline B & Jarang & 37 \\
\hline C & Tidak Pernah & 0 \\
\hline
\end{tabular}


Dari hasil kuisioner yang diajukan kepada 100 (seratus) responden pengendara Piaggio Vespa tentang seberapa sering responden mendengar nama Piaggio Vespa sebagai sepeda motor jenis scooter ketika bertemu dengan teman/keluarga, hasil penelitian memperlihatkan $63(63 \%)$ menyatakan sering mendengar Piaggio Vespa, sementara 37 (37\%) menyatakan jarang mendengar Piaggio Vespa, sedangkan $0(0 \%)$ menyatakan mereka tidak pernah mendengar Piaggio Vespa.

\section{c. Piaggio Vespa Sering Dilihat Di Iklan/Promosi Media Cetak}

Tabel 14. Piaggio Vespa Sering Dilihat Di Iklan/Promosi Media Cetak

\begin{tabular}{|c|l|c|}
\hline \multicolumn{2}{|l|}{ Piaggio Vespa Sering Dilihat Di Iklan/Promosi Media Cetak } & 100 \\
\hline A & Sering & 23 \\
\hline B & Jarang & 69 \\
\hline C & Tidak Pernah & 8 \\
\hline
\end{tabular}

Sumber : Data diolah, 2018

Dari hasil kuisioner yang diajukan kepada 100 (seratus) responden pengendara Piaggio Vespa tentang Piaggio Vespa sering dilihat di Iklan/Promosi Media Cetak, hasil penelitian memperlihatkan 23 (23\%) menyatakan jarang melihat iklan/promosi Piaggio Vespa di media cetak, sementara 69 (69\%) menyatakan sering melihat iklan/promosi Piaggio Vespa di media cetak, sedangkan $8(8 \%)$ menyatakan tidak pernah melihat iklan/promosi Piaggio Vespa di media cetak.

\section{d. Piaggio Vespa Sering Dilihat Di Iklan/Promosi Media Elektronik}

\section{Tabel 15. Piaggio Vespa Sering Dilihat di Iklan/Promosi Media Elektronik}

\begin{tabular}{|c|l|c|}
\hline \multicolumn{2}{|c|}{$\begin{array}{c}\text { Piaggio Vespa Sering Dilihat Di Iklan/Promosi } \\
\text { Media Elektronik }\end{array}$} & 100 \\
\hline A & Sering & 35 \\
\hline B & Jarang & 56 \\
\hline C & Tidak Pernah & 9 \\
\hline
\end{tabular}

Dari hasil kuisioner yang diajukan kepada 100 (seratus) responden pengendara Piaggio Vespa tentang Piaggio Vespa sering dilihat di Iklan/Promosi Media Elektronik, hasil penelitian memperlihatkan sebanyak 35 (35\%) responden menyatakan sering melihat iklan/promosi Piaggio Vespa di media elektronik, 
sementara 56 (56\%) responden menyatakan jarang melihat iklan/promosi Piaggio Vespa di media elektronik, sedangkan $9(9 \%)$ responden menyatakan tidak pernah melihat iklan/promosi Piaggio Vespa di media elektronik.

\section{e. Merchandise Piaggio Vespa Tersebar Di Area Publik}

Tabel 16. Merchandise Piaggio Vespa Tersebar Di Area Publik

\begin{tabular}{|l|l|l|}
\hline \multicolumn{2}{|l|}{ Merchandise Piaggio Vespa Tersebar Di Area Publik } & 100 \\
\hline A & Sering & 49 \\
\hline B & Jarang & 45 \\
\hline C & Tidak Pernah & 6 \\
\hline
\end{tabular}

Sumber : Data diolah, 2018

Dari hasil kuisioner yang diajukan kepada 100 (seratus) responden pengendara Piaggio Vespa tentang merchandise Piaggio Vespa tersebar di area publik, hasil penelitian memperlihatkan 49 (49\%) menyatakan sering melihat merchandise Piaggio Vespa di area public, sementara 45 (45\%) menyatakan jarang melihat merchandise Piaggio Vespa di area publik, sedangkan 6 (6\%) menyatakan tidak pernah melihat merchandise Piaggio Vespa di area publik.

\section{3) Analisa Brand Awareness (Brand Recognition)}

Brand recognition, pada tahapan ini pelanggan mampu mengidentifikasi merek yang disebutkan.

\section{a. Dapat Mengidentifikasi Sepeda Motor Piaggio Vespa Secara Baik dan Benar}

Tabel 17. Dapat Mengidentifikasi Sepeda Motor Piaggio Vespa Secara Baik dan Benar

\begin{tabular}{|l|l|l|}
\hline \multicolumn{2}{|c|}{$\begin{array}{c}\text { Dapat Mengidentifikasi Sepeda Motor Piaggio Vespa } \\
\text { Secara Baik dan Benar }\end{array}$} & 100 \\
\hline A & Ya & 83 \\
\hline B & Tidak & 17 \\
\hline
\end{tabular}

Dari hasil kuisioner yang diajukan kepada 100 (seratus) responden tentang dapat mengidentifikasi sepeda motor Piaggio Vespa secara baik dan benar, hasil penelitian 83 (83\%) menyatakan dapat mengidentifikasi sepeda motor Piaggio Vespa secara baik dan benar, sementara 17 (17\%) menyatakan responden tidak dapat mengidentifikasi sepeda motor Piaggio Vespa secara baik dan benar. 
a. Identitas Sepeda Motor Piaggio Vespa yang Paling Diketahui

Tabel 4.18. Identitas Sepeda Motor Piaggio Vespa yang Paling Diketahui

\begin{tabular}{|l|l|l|}
\hline \multicolumn{2}{|l|}{ Identitas sepeda motor PIAGGIO VESPA yang paling diketahui } & $\mathbf{1 0 0}$ \\
\hline A & Logo yang unik & 5 \\
\hline B & Desain model berbeda dengan motor lainnya & 92 \\
\hline C & Ketersediaan spare part yang mudah didapat & 1 \\
\hline D & Harga yang terjangkau & 1 \\
\hline E & Lainnya & 1 \\
\hline
\end{tabular}

Sumber : Data diolah, 2018

Dari hasil kuisioner yang diajukan kepada 100 (seratus) responden pengendara Piaggio Vespa tentang identitas Piaggio Vespa yang paling diketahui, hasil penelitian memperlihatkan $5(5 \%)$ menyatakan identitas Piaggio Vespa yang paling mereka ketahui adalah logo yang unik, sementara 92 (92\%) menyatakan identitas Piaggio Vespa yang paling mereka ketahui adalah desain model Piaggio Vespa yang berbeda dari sepeda motor lainnya, 1 (1\%) menyatakan identitas Piaggio Vespa yang paling mereka ketahui adalah ketersediaan spare part yang mudah didapat, $1(1 \%)$ lainnya menyatakan identitas Piaggio Vespa yang paling mereka ketahui adalah harga Piaggio Vespa yang terjangkau yang terjangkau, dan 1 (1\%) menyatakan identitas Piaggio Vespa yang paling mereka ketahui adalah identitas Piaggio Vespa lain-lainnya.

\section{4) Analisa Brand Awareness (Unaware of Brand)}

Pada tahap unaware of brand pelanggan merasa ragu atau tidak yakin apakah sudah mengenal merek yang disebutkan atau belum. Tingkatan ini yang harus dihindari oleh perusahaan.

\section{a. Mengenal Produk Motor Piaggio Vespa Dengan Sangat Baik}

Tabel 4.19. Mengenal Produk Motor Piaggio Vespa Dengan Sangat Baik

\begin{tabular}{|l|l|l|}
\hline \multicolumn{2}{|l|}{ Mengenal Produk Motor Vespa dengan Sangat Baik } & $\mathbf{1 0 0}$ \\
\hline A & Ya & 87 \\
\hline B & Tidak & 13 \\
\hline
\end{tabular}

Sumber : Data diolah, 2018

Dari hasil kuisioner yang diajukan kepada 100 (seratus) responden tentang mengenal produk motor Piaggio Vespa dengan sangat baik, hasil penelitian memperlihatkan $87(87 \%)$ menyatakan mengenal produk motor Piaggio Vespa 
dengan sangat baik, sementara $13(13 \%)$ tidak mengenal produk motor Piaggio Vespa dengan sangat baik.

\section{b. Mengenal Produk Motor Piaggio Vespa Dari Teman/Keluarga}

Tabel 4.20. Mengenal Produk Motor Piaggio Vespa Dari Teman/Keluarga

\begin{tabular}{|l|l|l|}
\hline \multicolumn{2}{|l|}{$\begin{array}{l}\text { Mengenal Produk Motor Piaggio Vespa Dari } \\
\text { Teman/Keluarga }\end{array}$} & $\mathbf{1 0 0}$ \\
\hline A & Ya & 85 \\
\hline B & Tidak & 15 \\
\hline
\end{tabular}

Sumber : Data diolah, 2016

Hasil kuisioner yang diajukan kepada 100 (seratus) responden tentang mengenal produk motor Piaggio Vespa dari teman/keluarga, hasil memperlihatkan 85 (85\%) menyatakan mengenal produk motor Piaggio Vespa dari teman/keluarga, sementara $15(15 \%)$ responden menyatakan tidak mengenal produk motor Piaggio Vespa dari teman/keluarga.

\section{c. Mengenal Produk Motor Piaggio Vespa Dari Iklan/Promosi}

\section{Tabel 4.21. Mengenal Produk Motor Piaggio Vespa Dari Iklan/Promosi}

\begin{tabular}{|l|l|l|}
\hline \multicolumn{2}{|l|}{ Mengenal Produk Motor Piaggio Vespa Dari Iklan/Promosi } & $\mathbf{1 0 0}$ \\
\hline A & Ya & 42 \\
\hline B & Tidak & 58 \\
\hline
\end{tabular}

Sumber : Data diolah, 2018

Dari hasil kuisioner yang diajukan kepada 100 (seratus) responden tentang mengenal produk motor Piaggio Vespa dari teman/keluarga, hasil penelitian memperlihatkan 42 (42\%) menyatakan mengenal produk motor Piaggio Vespa dari iklan/promosi, sementara $58(58 \%)$ menyatakan tidak mengenal produk motor Piaggio Vespa dari iklan/promosi.

d. Reputasi Sepeda Motor Piaggio Vespa Lebih Baik Dibandingkan dengan Reputasi Motor Lainnya yang Sejenis

Tabel 4.22. Reputasi Sepeda Motor Piaggio Vespa Lebih Baik Dibandingkan dengan Reputasi Motor Lainnya yang Sejenis

\begin{tabular}{|l|l|l|}
\hline \multicolumn{2}{|l|}{$\begin{array}{l}\text { Reputasi Sepeda Motor Piaggio Vespa Lebih Baik Dibandingkan dengan } \\
\text { Reputasi Motor Lainnya yang Sejenis }\end{array}$} & $\mathbf{1 0 0}$ \\
\hline A & Ya & 94 \\
\hline B & Tidak & 6 \\
\hline
\end{tabular}

Sumber : Data diolah, 2018 
Dari hasil kuisioner yang diajukan kepada 100 (seratus) responden tentang reputasi sepeda motor Piaggio Vespa lebih baik dibandingkan dengan reputasi motor lainnya yang sejenis, hasil penelitian memperlihatkan 94 (94\%) menyatakan reputasi sepeda motor Piaggio Vespa lebih baik dibandingkan dengan reputasi motor lainnya yang sejenis, sementara $6(6 \%)$ menyatakan reputasi sepeda motor Piaggio Vespa tidak lebih baik dibandingkan reputasi motor lainnya yang sejenis.

\section{e. Merekomendasikan Sepeda Motor Piaggio Vespa Kepada Orang Lain}

Tabel 4.23. Merekomendasikan Sepeda Motor Piaggio Vespa Kepada Orang

\section{Lain}

\begin{tabular}{|l|l|l|}
\hline \multicolumn{2}{|l|}{ Merekomendasikan Sepeda Motor Piaggio Vespa Kepada Orang Lain } & $\mathbf{1 0 0}$ \\
\hline A & Ya & 88 \\
\hline B & Tidak & 12 \\
\hline
\end{tabular}

Sumber : Data diolah, 2018

Dari hasil kuisioner yang diajukan kepada 100 (seratus) responden tentang merekomendasikan sepeda motor Piaggio Vespa kepada orang lain, hasil penelitian memperlihatkan 88 (88\%) menyatakan akan merekomendasikan sepeda motor Piaggio Vespa kepada orang lain, sementara 12 (12\%) menyatakan bahwa responden tidak akan merekomendasikan sepeda motor Piaggio Vespa kepada orang lain.

\section{f. Sepeda Motor Piaggio Vespa Banyak Digunakan Orang}

Tabel 4.24. Sepeda Motor Piaggio Vespa Banyak Digunakan oleh Orang

\begin{tabular}{|l|l|l|}
\hline \multicolumn{2}{|l|}{ Sepeda Motor Piaggio Vespa Banyak Digunakan Orang } & $\mathbf{1 0 0}$ \\
\hline A & Ya & 68 \\
\hline B & Tidak & 32 \\
\hline
\end{tabular}

Sumber : Data diolah, 2018

Dari hasil kuisioner yang diajukan kepada 100 (seratus) responden tentang sepeda motor Piaggio Vespa banyak digunakan orang, hasil penelitian memperlihatkan 68 (68\%) menyatakan sepeda motor Piaggio Vespa banyak digunakan orang, sementara $32(32 \%)$ menyatakan sepeda motor Piaggio Vespa tidak banyak digunakan orang. 


\section{Kesimpulan}

Berdasarkan hasil penelitian dan pembahasan yang telah dikemukakan, maka kesimpulan yang dapat diambil dari hasil penelitian mengenai ANALISIS STRATEGI BRAND AWARENESS (TOP OF MIND, BRAND RECALL, BRAND RECOGNITION, UNAWARE OF BRAND) SEPEDA MOTOR PIAGGIO VESPA DI JAKARTA TAHUN 2018 adalah sebagai berikut :

1. Dari hasil penelitian ini produk sepeda motor Piaggio Vespa merupakan pilihan pertama sebagian besar responden, dengan kata lain produk motor Piaggio Vespa menjadi Top of Mind, terbukti sebanyak $88 \%$ menyatakan bahwa sepeda motor Piaggio Vespa merupakan pilihan pertama dalam membeli sepeda motor jenis scooter.

2. Demikian pula logo Piaggio Vespa yang mudah diidentifikasi, 98\% mampu mengidentifikasi logo Piaggio Vespa dengan mudah sebagai sepeda motor jenis scooter. Selain mudah diidentifikasi, logo Piaggio Vespa juga mudah diingat oleh orang, terlihat dari hasil 99\% menyatakan bahwa logo Piaggio Vespa mudah diingat oleh orang sebagai sepeda motor jenis scooter.

3. Top of Mind menggambarkan merek yang pertama kali diingat oleh responden atau pertama kali disebut ketika yang bersangkutan ditanya tentang suatu kategori produk. Dari hasil penelitian tentang Brand Awareness (Top of Mind), maka Piaggio Vespa sebagai sepeda motor jenis scooter pertama di dunia telah menjadi Top of Mind.

4. Dari penelitian ini tentang Brand Awareness (Brand Recall) memperlihatkan bahwa sebanyak 79\% menyatakan bahwa Piaggio Vespa merupakan motor jenis scooter yang sering disebut oleh masyarakat, dan 63\% menyatakan bahwa Piaggio Vespa merupakan motor jenis scooter yang sering didengar ketika bertemu dengan teman/keluarga.

5. Nama Piaggio Vespa sudah tidak asing lagi di telinga masyarakat. Dalam hal ini untuk lebih dikenal lagi oleh masyarakat, Piaggio Vespa perlu mengiklankan/mempromosikan produknya. Dalam meluncurkan iklan/ promosi Piaggio Vespa kurang agresif, baik melalui media cetak maupun elektronik, hal ini dibuktikan dari hasil survey sebanyak $69 \%$ jarang melihat 
iklan/promosi produk sepeda motor Piaggio Vespa di media cetak, 8\% tidak pernah melihat iklan/promosi Piaggio Vespa di media cetak dan hanya 23\% yang pernah melihat iklan/promosi Piaggio Vespa di media cetak. Maka dari itu Piaggio Vespa perlu gencar dalam hal iklan/promosi, berguna sebagai informasi untuk membuat pelanggan sadar (aware) akan produk Piaggio Vespa. Sebagai persuading untuk membujuk pelanggan supaya mencoba produk dan jasa yang diiklankan. Sebagai reminding agar iklan menjaga Piaggio Vespa tetap segar dalam ingatan para pelanggan. Iklan juga berperan membangun awareness pelanggan dan mereposisi produk Piaggio Vespa dengan merubah persepsi perilaku.

6. Dari media elektronik hanya $35 \%$ saja yang sering melihat iklan/promosi Piaggio Vespa Sering, 56\% responden jarang melihat iklan/promosi Piaggio Vespa dan 9\% tidak pernah melihat iklan/promosi Piaggio Vespa di media elektronik.

7. Merchandise dapat diartikan sebagai barang-barang yang diproduksi guna untuk keperluan penjualan. Produk yang dicetak logo perusahaan dan diberikan secara gratis untuk pelanggan potensial. Tujuan dari produk ini adalah untuk meningkatkan kesadaran pelanggan tentang perusahaan untuk terus-menerus mengingatkan pelanggan tentang perusahaan. Efek dari merchandise akan membuat orang berpikir tentang produk perusahaan sebagai satu-satunya dan solusi ideal bagi kebutuhan mereka. Salah satu manfaat utama dari merchandise adalah untuk mendapatkan lebih banyak pelanggan dan klien. Hal inilah yang harus diterapkan oleh Piaggio Vespa. Merchandise disebarluaskan untuk orangorang yang masih belum sadar tentang produk Piaggio Vespa dengan memberikan sampel produk atau merchandise. Hanya $49 \%$ yang sering melihat merchandise Piaggio Vespa di area publik, 45\% jarang melihat dan 6\% tidak pernah melihat merchandise Piaggio Vespa di area publik. Maka dari itu Piaggio Vespa perlu meningkatkan penyebaran merchandise di area publik agar masyarakat mengetahui tentang Piaggio Vespa dan akan menempatkan merek Piaggio Vespa dalam pikirannya. Penyebaran merchandise dapat digunakan untuk membangun merek Piaggio Vespa, menarik pelanggan baru, menunjukkan 
apresiasi kepada pelanggan lama dan mempromosikan produk dan jasa Piaggio Vespa tersebut.

8. Dari hasil penelitian ini mengenai Brand Recognition, dimana 83\% dapat mengidentifikasi sepeda motor Piaggio Vespa secara baik dan benar. Dari segi identitas, identitas sepeda motor Piaggio Vespa yang paling diketahui adalah desain model Piaggio Vespa yang berbeda dengan motor jenis scooter lainnya yakni sebanyak 92\%. Selama lebih dari 6 (enam) decade mendominasi segmen scooter, Vespa hingga saat ini menjadi contoh unik industry desain yang tidak akan pernah mati. Berkat inovasi baik teknologi maupun desain, membuat produk Vespa lambat laun berubah dari sebuah produk transportasi menjadi salah satu bagian dari sejarah sosial. Identitas kedua yang diketahui 5\% adalah logo Piaggio Vespa yang unik dan identitas Piaggio Vespa lainnya yang diketahui adalah ketersediaan spare part yang mudah didapat, harga yang terjangkau, dan lainnya masing-masing 1\%. Dari hasil penelitian tentang Brand Awareness (Brand Recognition), maka masyarakat perlu diingatkan kembali dalam pengenalan logo Piaggio Vespa, harga Piaggio Vespa yang harus dibandingkan dengan desain dan teknologi semakin maju juga canggih, serta ketersediaan spare part yang sudah banyak dijumpai.

9. Dari hasil penelitian ini mengenai Unaware of Brand, produk Piaggio Vespa tidak termasuk dalam kategori Unaware of Brand, hal tersebut terlihat dimana $87 \%$ mengenal produk motor Piaggio Vespa dengan sangat baik dan 85\% mengenal produk motor Piaggio Vespa dari teman/keluarga. Dalam segi reputasi sebanyak 94\% menyatakan reputasi sepeda motor Piaggio Vespa lebih baik dibandingkan dengan reputasi motor lainnya yang sejenis. Selama lebih dari 6 (enam) decade mendominasi segmen scooter. Vespa hingga saat ini menjadi contoh unik industri desain yang tidak akan pernah mati dan menjadi salah satu bagian dari sejarah social dan merupakan simbol dari kreativitas ala Italia yang termahsyur di seluruh dunia yang dibuktikan oleh kesuksesan penjualan dari tahun ke tahun. Vespa merupakan jenis kendaraan scooter yang banyak diminati oleh semua orang, 68\% menyatakan sepeda motor Piaggio Vespa banyak digunakan oleh orang. Bentuknya yang unik mampu membuat setiap orang 
merasakan sensasi tersendiri ketika mengendarainya. Produsen motor Piaggio merupakan produsen Vespa yang banyak diminati oleh pecinta motor Vespa Indonesia yang terdapat banyak jenis Vespa dari klasik hingga modern. Vespa memiliki banyak peminat, dapat dibuktikan dengan adanya berbagai komunitas pecinta Vespa di Jakarta. Dan 88\% responden akan merekomendasikan sepeda motor Piaggio Vespa kepada orang lain. Tetapi, hanya $42 \%$ yang mengenal Piaggio Vespa dari iklan/promosi. Hal ini yang yang harus Piaggio Vespa tekankan kembali dalam segi iklan/promosi, supaya masyarakat lebih mengenal Piaggio Vespa lebih jauh dan masyarakat menanamkan Piaggio Vespa dalam pikiran mereka.

10. Dari hasil penelitian tentang Brand Awareness (Unaware of Brand) diatas menunjukkan bahwa produk sepeda motor Piaggio Vespa tidak termasuk ke dalam bagian unaware of brand.

Berdasarkan penelitian ini untuk menciptakan dan meningkatkan STRATEGI BRAND AWARENESS SEPEDA MOTOR PIAGGIO VESPA DI JAKARTA hendaknya terlebih dahulu membangun dan mengembangkan ELEMEN TOP OF MIND, BRAND RECALL dan BRAND RECOGNITION, serta menghindari UNAWARE OF BRAND untuk semakin meningkatkan BRAND AWARENESS SEPEDA MOTOR PIAGGIO VESPA DI JAKARTA.

\section{Daftar Pustaka}

Aaker, David A. 1996. Buildng Strong Brands. The Free Press. New York.

Industri Automotive, www.indutri-nasional.blogspot.co.id

Kartajaya, Hermawan. 2009. The Official MIM Academy Coursebook, Markplus Basic. Penerbit Erlangga. Jakarta.

Kartajaya, Hermawan. 2007. MarkPlus on Marketing, The Second Generation. Gramedia Pustaka Utama. Jakarta.

Miro, Fidel. 2012. Pengantar Sistem Transportasi. Penerbit Erlangga. Jakarta.

Nazir, Moh. 2009. Metodologi Penelitian. Ghalia Indonesia. Jakarta.

Schipper, Lee. 2002. Sustainable Urban Transport in the 21th Century : Challenges for Developing World. MacMillan. New Delhi. 
Relasi : Jurnal Ekonomi, Vol. 15, No. 1, Januari 2019, hlm. 113-134

Sugiono. 2005. Metode Penelitian Bisnis. Pusat Bahasa Depdiknas. Bandung. 